\title{
Diversification and Livelihood Sustainability in a Semi-arid Environment: A Case Study from Southern Ethiopia
}

\author{
Wassie Berhanu**, David Colman**, and Bichaka Fayissa* \\ **University of Manchester, UK \& *Middle Tennessee State University
}

\begin{abstract}
This paper examines the recently growing adoption of non-pastoral livelihood strategies among the Borana pastoralists in southern Ethiopia. A large portion of the current non-pastoral participation is in petty and natural resource-based activities. Pastoral and crop production functions are estimated using the Cobb-Douglas model to analyse the economic rationale behind the growing pastoralist shift to cultivation and other non-pastoral activities. The low marginal return to labour in traditional pastoralism suggests the existence of surplus labour that can gainfully be transferred to non-pastoral activities. An examination of the pastoralist activity choices reveals that the younger households with literacy and more exposure to the exchange system display a more diversified income portfolio preference. The findings underscore the importance of human capital investment and related support services for improving the pastoralist capacity to manage risk through welfare-enhancing diversified income portfolio adoption.
\end{abstract}

Key words: Pastoralism, Dryland Farming, Diversification, Production Functions, Ethiopia

JEL category: D00, I30, J20, O12

*Bichaka Fayissa, Professor, Department of Economics and Finance, Middle Tennessee State University, Murfreesboro, TN 37132, phone: 615-898-2385, fax: 615-898-5596, email: bfayissa@mtsu.edu. ${ }^{+}$This paper is an early version of an article published in the Journal of Development Studies, 43(5), 2007:871-889. 


\section{Diversification and Livelihood Sustainability in a Semi-arid Environment: A Case Study from Southern Ethiopia}

\section{Introduction}

This paper examines the patterns and implications of the current livelihood diversification behaviour among the Borana pastoralists in southern Ethiopia. Pastoralists are people who rely on domestic livestock for most of their income. Pastoralism is their way of life (Sandford 1983, Swift 1986). Traditional pastoralism is based on the use of natural pasture and is practiced in dry environments where rainfall is generally unreliable for sustainable crop-based livelihoods. There are some distinctions in pastoral typologies which mainly arise due to differences in the level of mobility, the type of species managed, and economic orientation (Pratt et al., 1997).

Diversification is a core strategy of contemporary rural livelihood systems in developing countries (Ellis 2000, Barrett et al. 2001a, Reardon 1997, Reardon et al. 2001, Niehof 2004). Despite past development interventions, East African pastoral systems are presently characterised by a dwindling asset base, human welfare deterioration, and the consequent household-level response of poverty driven lowreturn non-pastoral engagements (Coppock 1994, Little et al. 2001, Fratkin and Mearns 2003, McCabe 2003, Desta and Coppock 2004). These have mainly been caused by recurrent droughts and conflicts which pose serious threats to pastoral household viability in dryland environments. Population growth, intrusive external interventions, and inexorable loss of pastoral grazing lands due to the continuous 
pressure of territorial contraction resulting from range encroachments by farming cultures and heedlessly expanding commercial agriculture are among the often quoted major trends that have profoundly threatened pastoralist livelihoods in Africa (Swift and Hamilton 2001). The deteriorating quality of the natural resource base, declining productivity, and falling animal per capita have resulted in pastoral food insecurity (Webb and Coppock 1997), often forcing traditional herders to seek alternative livelihood options. East African pastoralists have always sought non-pastoral alternatives both to survive the effects of catastrophic shocks and in response to market opportunities (Dahl 1979, Horowitz and Little 1987, Sperling and Galaty 1990, Rutten 1992, Coast 2002). However, the recently increasing adoptions of natural resource-based non-pastoral income strategies such as dryland farming, underscore the need for systematic inquiries into the underlying determinants and their implications for sustainable livelihoods in these fragile environments.

The mainstream household economic theory may serve as a point of departure for the analysis of rural household diversification behaviour (Ellis 1998, 2000). It considers diversification as a rational economic behaviour adopted in given circumstances of constraints and opportunities. Household economic models (Singh et al. 1986) assume that rural households make free choice decisions of allocating their labour and material resources to alternative activities in response to the comparative returns of these engagements. Under perfectly competitive assumptions, the simple economic rule that governs household labour allocation decisions is that an effort invested in any activity increases until the marginal return to its resource use equals that of alternative occupations. The optimal point of the division of household time among various competing alternative activities is achieved at equilibrium where their marginal returns are ultimately equalized (Polzin and MacDonald 1971). It follows 
from this abstract economic logic that while household participation in non-pastoral activities should increase in response to higher marginal returns in these activities, it will be inversely related to the level of shadow wages in traditional pastoralism. We test this by estimating the productivity of labour (shadow wages) in traditional pastoralism and assess what it means in terms of the pastoralist current labour allocation decisions. The household economic theory is analytically restrictive because of its well functioning market assumptions and several other caveats. In reality, rural households' resource allocation decisions are fundamentally constrained by conditions of livelihood asset endowments and related socio-political and institutional factors (Dercon and Krishnan 1996, Ellis 2000, Barrett et al. 2001b). With critical consideration of the pastoralist livelihood context, other determinants of household activity choice are, therefore, empirically examined using the multinomial logit model.

The rest of this paper is organised as follows. The next section is devoted to a brief description of the study area. Section three presents details of Borana household non-pastoral activity participation. The comparative returns of the pastoralist main activity engagements are estimated in section four. The determinants of pastoral household adopted activity portfolio strategies are examined in section five. The final section attempts to draw policy conclusions based on the findings.

\section{The Study Area and the Data}

Borana pastoralism remains a significantly attractive area of study partly because of its livestock resources, institutional peculiarity, and relative ecological potential. The Borana pastoralists live in southern Ethiopia and northern Kenya; their grazing territory in Ethiopia is conventionally estimated to be $95,000 \mathrm{~km}$. Based on 
official government projections, the currently estimated pastoral population in the study area is about 460,000 , although this must be treated with caution. A point of special mention concerning the Borana society is about its Gada institution. The Gada is a complex traditional democratic system of self-rule that governs the social, economic, political and spiritual life of the Borana society (Legesse 1973, 2000). The supreme legislative organ of the Borana traditional self-rule is the Gumi Gayo, which is the general assembly of the Borana from all grazing territories of Boranaland. The Gumi Gayo is a forum of deliberations and traditional policy making for dynamic adjustment of the Borana society to its contemporary circumstances.

The Borana area is characterised by its very erratic bi-modal rainfall pattern with an annual average range of $400-700 \mathrm{~mm}$, which generally is also an increasing function of altitude (Coppock 1994, Desta and Coppock 2004). The annual cycle of precipitation in the area is basically different from that of the highland regions in Ethiopia. The main rainy season is the ganna period from mid-March to May. The Hagayya season is normally a period of short rains of September to November. The Borana long dry season (Bona) is normally from mid-November to mid-March, but is often longer because of rain delays and/or failure of the short Hagayya rains. The June-August period is the intermediate cool dry season of Adollessa.

The largest portion of Borana landscape is more suited for cattle production (Oba 1998). The Borana also keep goats, sheep, and camels. A succinct description of the physical and climatic features of the Borana pastoral system is given by Coppock (1994).

The data used in this study are generated by a cross-section pastoral household survey that covered the period between October 2002 and end of July 2003. A total of 150 households were randomly chosen from villages in four selected study sites 
(Dhas, Dhoqole, Dubuluq and Romiso), ranging from peri-urban to remote locations.

Two households migrated during the course of the repeated-visits survey. The data collection approach rigorously used a blend of quantitative and qualitative techniques. Tabular questionnaires (for definition, see Casley and Lury 1987) were used in obtaining the core quantitative data continuously gathered through bi-weekly repeated-visits sample household interviews. Supplementary data on a wide range of issues were also obtained using verbatim questionnaires. Qualitative information was gathered through observational methods, informal group discussions, key-informant individual interviews, and a focused group discussion with about 20 highly experienced elders from different grazing territories of Boranaland. Our empirical results are interpreted in the light of these field investigations.

Given the sensitivity of a great part of our inquiries, there was a conscious effort to gain a high standard in the quality of information gathered by adopting various interviews and rigorous verification techniques in the data collection and survey administration processes. The multi-visit interview approach was found to be useful for addressing the classic problem of getting reliable pastoral income data often encountered in single-visit direct interviews. The interviewers stayed among the community for the entire survey period, offering a wider opportunity to obtain more realistic pastoral herd data. The participatory wealth ranking exercise adopted at the initial stage of sample selection was also useful in the above effort. A quantitative household economic survey among a traditional pastoral community is, however, not entirely immune from pitfalls; there usually remains a case for cautious treatment of reported income levels of especially households in high wealth categories.

\section{The Extent and Patterns of Non-Pastoral Participation}


The extent and pattern of Borana livelihood diversity is discussed in this section, first starting with brief definitions of the different categories of pastoral household income.

\section{a) Definition of pastoral household income sources}

Pastoral household income sources may be classified into three main categories. These are: pastoralism, dryland farming, and non-farm non-pastoral (NFNP) activities. Since farming and pastoralism are essentially different activities, the former is considered as a form of pastoralist income diversification; farm income is a non-pastoral income. All other non-pastoral activities are, hence, classified as non-farm non-pastoral (NFNP) activities. The income from pastoralism, in turn, consists of milk off-take for own consumption and sales, livestock slaughter for own consumption, livestock sales, and miscellaneous income from sales of hides and skins. The sum of values of these product components then gives gross pastoral income. Pastoral net income is found by deducting livestock expenditure. The costs of veterinary drugs and mineral salt purchases are the main items of expenditure in the Borana livestock production system.

The non-pastoral revenue components include farm income and earnings from various non-pastoral activities. The net farm income is the difference between the gross value of production (sum of values of crops produced by individual households both for own consumption and sale during the main and short rainy seasons of the survey period) less input costs (costs of seed input and hired labour). None of our sample Borana households reported any use of fertilizer and other agro-chemical inputs. NFNP income sources include a variety of activities which are indicated in a section below. Recorded net earnings from various NFNP self-employment activities 
are obtained after appropriately deducting the costs of various inputs from gross earnings.

\section{b) The Borana wealth ranking categories}

We used the community criteria in the sampling stratification of Borana households. The status of wealth among the Borana is measured by the size of cattle ownership. ${ }^{1}$ Cattle are considered to be of "complete function" because of both their economic superiority and the unique social value attached to them (based on discussions with Borana elders). Four wealth categories were identified during the participatory wealth ranking exercises. These are Qolle (very poor), Deega (poor), Bultiqabesa (middle wealth) and Duresa (rich). This classification is centrally tied to the Borana Busa-Gonofa indigenous welfare system. Five head of cattle is traditionally considered to be the basic minimum to establish a family. A person with less than this traditionally established minimum is considered to be poor. A person without cattle is called Qolle (very poor). In the tradition, a person with more than 10 head of cattle was considered to be rich, albeit that this traditional criterion is losing its currency due to declining productivity and growing family sizes.

A great majority of female-headed households are found in the two bottom quartiles. Female-headed households constitute 15.3 per cent of the households in the sample. This group is relatively poorer with an average reported livestock size of seven livestock units (LUs) as compared to the average 26.4 LUs for the male-headed group. Generally, the monthly mean income per capita runs from 35 birr (US \$ 4) for the lowest community wealth ranking quartile (the very poor) to 155 birr (US \$ 18) for the highest ${ }^{2}$ (Table 1).

\section{c) The size and pattern of household income diversification}


From column 6 of Table 1, it is found that pastoralism still remains the principal source of Borana livelihood, accounting on the average for 72 per cent of the sampled household income; arable farming with an average share of 18 per cent is a distant second to pastoralism. The NFNP sources account for an average of 10 per cent, reflecting their recent emergence. Data are scarce to quantitatively compare the extent of Borana livelihood diversity with other East African systems, though it is known that the economies of pastoral groups like the Maasai have long been influenced by profound market developments such as international tourism to widen the scale of their income diversity (Rutten 1992, Campbell 1999, Desta and Coppock 2004). Income diversification in the area generally appears to follow a U-shape pattern, and the strategy is largely adopted by the poor for survival. Reardon et al. (2000) attribute this phenomenon to the availability of high labour-to-capital ratio jobs which have low entry barriers, allowing poor people to find jobs easily. Moreover, such redistribution of non-farm incomes is more probable if infrastructure is relatively good, population and market densities are high, the agricultural sector is dynamic, landholdings are unequal, and the degree of urbanisation of the rural area is high. The low level diversification in the middle would depend on households in the mid-range being able to specialise in crop production, while richer households are able to diversify into more capital intensive activities. The NFNP income share is the highest for the poorest group; it substantially drops for the middle rank and rises again for the highest wealth category. For the very poor, diversification is a key strategy for survival while the rich are mainly motivated to diversify in response to wealth accumulation opportunities for welfare enhancement. Coping as a survival strategy in response to shocks and consequent substantial asset loss (Ellis 2000) profoundly 
entails more involvements of poor households in traditionally uncommon livelihood pursuits.

In term of income shares, the level of reliance on pastoralism increases with wealth status. Table 1 also shows that farming income share is inversely related to average household per capita income levels. The very poor derive nearly 44 per cent of their income from farming as compared to 30.4 per cent for the poor and only 10 per cent for the rich category. However, as shown in Table 2, farming figures less prominently in the non-pastoral income portfolio of the very poor whose activity mix rather exhibits a comparatively higher NFNP component. In percentage terms, farming is a much larger source of non-pastoral income for the second and third wealth ranking categories than it is for the very bottom and the top ones.

Farming in the Borana tradition had been considered falfala (evil or disgraceful), perhaps, because of its perceived resource competition with livestock production; it was only formally allowed by the 1972 Borana Gumi Gayo assembly. The 1996 assembly, according to Gollo Huqqaa (n.d), further upheld the promotion of farming in the area. Huqqaa records this motion as being justified by the development of a taste for cereal consumption, decreasing cattle productivity, and shrinking grazing land. The sustainability of this change is, however, quite questionable due to the possible long-term environmental repercussions of the recent pervasive rangeland colonisation for arable farming.

The extent and pattern of pastoral household reliance on different categories of non-pastoral activities is shown in Table 2. Participation in natural resource-based activities accounts for 20.3 per cent of the NFNP income reported by the very poor household groups; quite strikingly, it is 50.1 per cent for the households group in the middle wealth rank. Charcoal burning and forest wood selling are not activities 
necessarily practiced by the very poor alone. The principal aim of a stock owning charcoal burner, or forest wood seller is to minimise livestock sales which are, otherwise, often required to meet the basic cash needs of the household.

Next to farming, the largest portion (41.3 per cent) of the reported nonpastoral earnings of the rich is from livestock trade and small business. ${ }^{3}$ From our survey data, reported income from these activities accounts for 47 per cent of the entire sample of NFNP earnings, but is generated by only 5 per cent of the sample pastoral households. The adoption of these commercially-oriented household livelihood strategies is of paramount importance principally due to their complementary significance to the livestock economy and the positive risk management implications.

For the very poor, the petty trade and crafts activity category (see notes to Table 2) is the second most important source of income, next to casual labour earnings. It is an income category which represents a significant level of household participation across all wealth categories. Casual labour activities, though quite limited in the area, are important sources of income for the very poor. A considerable portion of household casual labour earning is obtained from farm work. Hired farm labour demand in the area is, however, very low because of the erratic nature of the farming activity and the presence of strong cooperative labour arrangements. Labour markets have not yet developed in the herding sector and the livestock economy largely benefits from borrowed labour and strong cooperative arrangements of the system. In our case, formal employment earning was only found for the limited local opportunities offered by church and NGO activities which are normally available to only a few individuals with some level of education. 
Migrant remittance is not an important source of household income in the Borana area. The urban connection is an extremely feeble pathway to the source of livelihood for the marginalized Borana. During the repeated household survey assessments, only 3 per cent of the households reported a departure, only of a stressed autonomous type of a member of their household. Reported out-migration of a family member to urban areas in recent years is virtually nil for all interviewed sample households. Inter-household cash gift is the most important component of income transfers to pastoral households.

\section{Estimation of Returns to Labour in Farming and Traditional Pastoralism}

From his field investigations in the 1960s, one of the distinguished scholars on Borana ethnography wrote: 'They [the Borana] have nothing, but contempt for those who stoop to till the soil' (Legesse 1973, p.17). Nowadays, however, the Borana have generally become enthusiastic land tillers. Here, we turn to the investigation of the economic rationale behind the prevailing practice of increasing pastoralist involvement in arable farming and other non-pastoral activities. Livestock and crop production functions are estimated in order to compute their comparative marginal returns and to assess their implications for the pastoralist seasonal labour allocation decisions.

\section{a) The statistical model specification}

Assuming continuous and differentiable production functions for pastoral and farming activities, the estimation procedure uses the Cobb-Douglas (C-D) production technology generally represented by the functional form:

$$
\mathrm{Q}=\Omega \mathrm{L}^{\alpha} \mathrm{K}^{\beta}
$$


where $\mathrm{Q}$ denotes output, $\Omega$ positive constant, and L and $\mathrm{K}$ are labour and capital inputs, respectively. ${ }^{4} \alpha$ and $\beta$ are positive fractions representing elasticities of output $\mathrm{Q}$ with respect to $\mathrm{L}$ and $\mathrm{K}$ inputs, respectively. The sum $\alpha+\beta$ gives the degree of returns to scale. For empirical estimation, a double-log transformation of equation [1] is written as:

$$
\ln Q=\ln \Omega+\alpha \ln L+\beta \ln K+\varepsilon,
$$

The shadow wages (marginal products) of household labour are empirically computed means estimated using the formula:

$$
M P L_{i}=\frac{\alpha_{i} \hat{Q}}{L_{i}}
$$

where $\hat{Q}$ is the predicted value of output derived based on the estimated equation, $\alpha$ is the respective value of the partial elasticity coefficient and $\mathrm{L}_{\mathrm{i}}$ total hours of household labour (Jacoby 1993, Skoufias 1994).

For empirical estimation, the definitions and descriptive statistics of variables in the livestock and crop production functions are summarised below in Table 3.

\section{b) Variable definition and estimation}

Livestock production function estimation is less common than crop function estimations; it is usually problematic because of the implied measurement difficulties (Jacoby 1992, 1993). The special case about the mobile pastoral mode of production is that, unlike in farming systems, land is not a fixed factor for the individual producer and livestock are the key capital input. It is extremely difficult to measure the size of land input for individual stockowners in mobile pastoral systems.

Pastoralists produce milk and meat. The amount of milk produced depends on the scale of pastoralist labour efforts in various livestock production activities. A more 
difficult issue is how to account for the meat component of pastoral output. In a case study of a mixed farming system, (Jacoby 1992) indicates the special difficulty of the livestock component in farm household production function estimation.

Here, the total value of pastoral production $(\mathrm{P})$ is the dependent variable in the estimation of the livestock production function. It is the sum of values of milk and meat off-takes, both marketed and unmarketed. Concerning meat off-takes, the value of estimated annual stock appreciation may be additionally included as a measure of return to the pastoralist labour efforts as pointed out in (Jacoby 1992). However, this is not considered here due to lack of reliable data on pastoral herd growth rates and weight gains.

The input variables in the livestock production function estimation are pastoral labour (L) and livestock capital (K). ${ }^{5}$ The pastoral labour input is measured in total hours used by a household in identified areas of animal production activities that include herding and watering different classes of livestock, milking animals, calf feeding, animal dung removal and cleaning activities, construction of corral, and management activities. It is hours used by all working members of sample pastoral households for the survey period and converted into adult equivalent.

Turning to the crop production function, the dependent variable $(\mathrm{C})$ is the total value of crop production per household. The households reported quantities of different crops, and these are valued at average local market prices. The labour input (F) is reported hours used in farm operations ranging from land clearing to crop harvesting. It is mainly a family labour, but also includes any hired as well as borrowed labour. The land input $(\mathrm{N})$ is the area cultivated and is measured in Sangas, which is a standard local unit representing an average area of land worked by a pair of oxen per cultivation day. ${ }^{6}$ Oxen power $(\mathrm{O})$, measured in oxen days, is also included. 
Respectively, additive location dummies $\mathrm{L}_{1}, \mathrm{~L}_{2}$, and $\mathrm{L}_{3}$ for Dhas, Dhoqolle, and Dubuluq sites are introduced in order to capture effects such as inter-village climatic variations and differences in farming experience. ${ }^{7}$ The peri-urban Romiso village is taken as the basic point of reference. The 2002 main season crop production data are used in the estimation. All households that reported some level of crop output for that period are included. Profitable use of artificial fertilisers and improved seed varieties appears to have been ruled out in the area apparently because of the moisture deficit in the dryland soil.

It may be important to stress at this point that, despite all the efforts, recall errors are almost inevitable in this kind of exercise. The recall problem in this study is probably less pronounced for the labour data on livestock production than for crops. The livestock production labour data were specially generated by a detailed repeatedvisits routine recall interviews and observations of household time use by all working members over the entire survey period. However, as is usually the case, the crop labour data were collected in single-visit interviews which inevitably entail unavoidable recall errors. The crop production data are typically sensitive to the erratic climatic conditions of the area; but our conclusions are based on a normal year assumption.

\section{c) Results and implications}

The OLS estimates of the Cobb-Douglas production functions are displayed in Table 4. The models explain the data with strong level of significance. The coefficient estimates are consistent with a priori expectations. As can be seen, the coefficients of the livestock production variables are strongly significant. The livestock production elasticities in the C-D model add up to one consistent with the theoretical assumption of constant returns to scale. Perhaps, a rather important case here is that the largest 
share (84 per cent) of the output generated in the pastoral production system is contributed by livestock capital. Other things being equal, a 10 per cent increase in livestock capital leads to nearly 9 per cent increase in pastoral output.

With respect to crop production estimates, the land and oxen coefficients, though positive, are found to be statistically insignificant. Dryland farming practice in the area is generally influenced by the extreme variability and erratic nature of climatic conditions both across villages and seasons. A partial abandonment of cultivated land is sometimes quite common. The problem appears to be compounded by the prevailing poor practices of inadequate land preparation and crop management experience. As can be seen, the effect of location on farm output is strongly significant. It is partly indicative of the state of pastoralist cultural practice in the arable farming area. Peri-urban cultivators are relatively more experienced in land preparation and crop management practice than pastoralists in remote locations such as Dhas, or than those at locations of a recently increasing household new involvement in arable farming (for example, Dubuluq). Overall, the results show that the benefit of farming is, perhaps, rather better maximised through labour intensification in adequate farming and crop management practices than the apparently wasteful ambitious horizontal expansion.

Table 5 shows returns to labour from selected activities. The marginal and average returns to labour from pastoralism, dryland farming, and natural-resourcebased income generating activities are derived from estimated model coefficients. The return estimates for the natural-resource-based activities are similarly based on the CD model, but only with labour input. The elasticity coefficient is statistically significant at 1 per cent level, but it needs to be cautiously treated because the estimation is based on a small number of sub-sampled households. ${ }^{8}$ The estimation of 
marginal, or average returns for a variety of other NFNP activities was not possible because of the size inadequacy of household sub-samples in these activities. The return for casual farm work is a simple average of on-farm wage earnings over hours of labour hired out by some poor households in the sample. ${ }^{9}$

The estimates presented in Table 5 are informative as to the productivity of labour and the nature of its use in the Borana pastoral production system. The estimated shadow wage rate in traditional pastoralism is lower than returns in nonpastoral activities. The computed values of the marginal productivity of labour in farming and natural-resource-based activities are higher than that of the livestock activity. The low marginal return in traditional pastoralism indicates the availability of surplus labour in the system that can more productively be transferred to unskilled non-pastoral occupations. All the same, pastoralists at the moment heavily rely on the relatively higher average and total return from their livestock capital. The average return is higher in traditional pastoralism simply due to the very large proportional contribution of livestock capital. This higher average return in pastoralism along with the system's robust social organization appears to have sustained many household members who make little marginal contribution. ${ }^{10}$

Moreover, despite some key sustainability issues, there is a fairly strong shortterm economic justification for Borana households' increasing involvement in the previously frowned upon activity of dryland farming. Farming is apparently attractive for several reasons. Firstly, its apparent higher marginal returns to labour provides a better outlet for the labour of families with little livestock capital than does committing to pastoralism. The lower marginal return to labour in traditional pastoralism implies a readily availability of surplus household labour for other activities. Secondly, arable farming may attract large stock owners because of its 
apparent contribution to the central objective of livestock capital accumulation through the minimization of off-takes required for grain purchases.

Thirdly, the results inform about the Boranas' new experience of household "labour smoothing" strategy in which they switch from pastoralism to the relatively higher return farming activity during the wet seasons. Seasonality means variations in periodic returns to labour time in different occupations during parts of the year (Ellis 2000). The labour requirement in pastoralism is basically continuous. However, the dry period in Borana pastoral area is a time of high labour demand for watering animals from deep traditional wells. The Borana pastoralists normally reserve their young labour force for this arduous task of dry season water lifting. Given the limited other non-pastoral options, they have now learned to release this "labour reserve" for more gainful use in the dryland farming occupation during wet seasons.

Farming and pastoralism are, however, highly competitive in their use of the natural resource base (that is, more fertile land) of the system. It is this latter aspect that triggers a concern for the long-term implications of the presently expanding crop cultivation practice in Boranaland. The results also indicate that doubling efforts in the dryland farming activity do not seem to result in equi-proportional output response because of the apparent low productivity of the semi-arid environment.

\section{The Determinants of Household Activity Choice}

Using a similar methodological approach to Dercon and Krishnan (1996), five activity categories are identified to gain some insights as to the determinants of pastoral household activity choice. The level of Borana household participation in each activity category is shown in Table 6. 
Households that adopt the first activity category (AP1) participate in pastoralism, farming, and high return activities such as livestock trade, wage employment, and other relatively more capital-intensive engagements. This activity category is adopted by higher income households. The second activity category (AP2) is adopted by a considerable portion ( 25 per cent) of households that, in addition to pastoralism, do allocate their labour to farming plus one or more of those diverse low return activities such as casual labour, dairy marketing, crafts and various petty trading activities. Besides some level of earning in pastoralism and farming, a number of households have recently been forced to rely on soft-target natural-resource-based activities such as forest wood selling, charcoal making, and firewood collection, which characterise the third activity portfolio (AP3). This activity (AP3) is thus largely adopted by the low-income group of households that, on the average, presently generate a computed nearly 70 per cent of their income from non-pastoral sources. A few of the households that adopt this activity category have had their pastoral income earning power severely curtailed by wealth loss and stocklessness. The most popular and recent pastoral household activity mix, adopted by 45.2 per cent in the sample, in the Borana area is pastoralism combined with farming (AP4). The fifth category (AP5) is pure pastoralism.

A multinomial logit model is used to examine the determinants of alternative household activity-mix strategies. Multinomial logit analysis is a widely used technique in applications that analyse polytomous response categories in different areas of economic and social studies. The central concern here is to explain factors that determine the probabilities of household engagement in alternative non-pastoral activity categories. 
The behavioural notion of the model may be invoked here by considering pastoral households as rational decision makers. Households are assumed to adopt an activity portfolio choice that maximizes their utility from the expected earning gains from these activities (Dercon and Krishnan, 1996). The utility that can be obtained by a household $\boldsymbol{h}$ from a choice category $\boldsymbol{j}$ is fundamentally associated with: a) the attributes of the activity categories such as their capital and skill intensity, the nature of their local demand and rate of return to factor inputs; and b) the characteristics of the individual household decision maker: the household's demographic characteristics, asset endowments, tastes, risk preference, and location factors. The observed pattern of household's activity engagement is then considered to be a reflection of its revealed rational choice subject to these conditions (Barrett et al. 2001b).

The discrete choice formulation of the utility maximisation assumption for individual household $\mathbf{h}$ that chooses from the $\mathbf{j}$ alternatives is usually expressed as:

$$
U_{h j}=\bar{U}_{h j}+\varepsilon_{h j}=X_{h j}{ }^{\prime} \beta+\varepsilon_{h j}
$$

where $\bar{U}_{h j}=X^{\prime}{ }_{h j} \beta$ represent the deterministic components of the utility function and $\varepsilon_{h j}$ a vector of the random component representing unobserved attributes, tastes and measurement errors (Ben-Akiva and Lerman 1985). The symbol $\beta$ denotes a vector of coefficients representing the effects of the independent variables denoted by the $\mathrm{X}$ vector. The two categories of attributes mentioned above that constrain individual household utility maximization choice are supposed to be embedded in the explanatory variables vector $\mathrm{X}$. Nevertheless, the attributes of the choice categories often apparently remain notional in the context of many empirical applications due to lack of data (Judge et al. 1985). 
The explanatory factors in the multinomial regression of pastoralist activity choice could be categorised as household level attributes which include household demographic characteristics, asset endowments, and access to opportunities represented by distance. These are represented by the explanatory variables of gender of the household head (FEMHEAD), age of the household head (AGE), household size (HHSIZE), size of household male workforce (MALE15-64), wealth status (STOCKSIZE), level of education (EDUCATION) and distance from the nearest town (DCENTRE).

The results are shown in Table 7 . The pastoralism-farming activity mix is taken as a base for comparison. The likelihood of adopting activity portfolio 1 (AP1) versus the currently most common activity mix (AP4) is significantly determined by gender, age, household size, wealth status and level of education. The probability of choosing the activity portfolio strategy with high return non-pastoral element (AP1) decreases with age as well as being female-headed. As expected, it does, however, increase with wealth status and education. ${ }^{11}$ It is the rich and younger pastoralists with some level of education or exposure that are generally found to be involved in relatively high return non-pastoral occupations. The likelihood of involvement in the latter as opposed to the base category decreases with distance, but the coefficient is not statistically different from zero. It shows an emerging positive tendency where, regardless of location, the new generation of rich and relatively enlightened Borana pastoralists is considering investment of their livestock proceeds in high return nonpastoral alternatives.

Activity portfolio categories AP2 and AP3 are strategies mainly adopted by the relatively poor and the stockless. The likelihood of adopting these activity portfolio strategies significantly increases with being female-headed, decreases with 
wealth status, and is positively associated with household size. The difference between the two pastoral household activity portfolios is that distance is a significant explanatory factor in the choice of AP3 which largely includes firewood collection and charcoal making. This latter strategy can normally be adopted only by those around towns, or near the main road to particularly satisfy the charcoal and fuel-wood demands of urban dwellers.

With respect to pastoralism and farming, the probability of non-pastoral activity choice decreases with age, other things being equal. The likelihood of remaining in pure pastoral activity increases with age and decreases with the household size. Older households with smaller workforce tend to remain in pure pastoralism (AP5). Despite the limited opportunities, the current younger generation of Borana pastoralists shows a higher propensity to hunt for alternatives outside traditional pastoralism both for survival and wealth accumulation. The likelihood of remaining in pastoralism activity increases with wealth status, but surprisingly this is statistically insignificant. It particularly indicates the recent increasing participation of wealthy pastoralists in dryland farming. Contrary to expectations, the likelihood of sticking to pure pastoralism as compared to farming is not generally influenced by distance from towns which reflects the currently mushrooming rangeland enclosures for arable cultivation in many remote pastoral villages.

\section{Conclusion}

The Borana pastoral area has usually been considered as a potential source of surplus for national economic growth owing to its relatively huge livestock resources. The problem of failure to realise this perceived potential is at the same time ascribed to the pastoralists' recalcitrant attitude to change. Nevertheless, poverty driven 
income diversification is currently becoming an important aspect of the pastoral livelihood dynamics when compared to the past. Centrally driven by external shocks and trends in the system, the Borana household livelihood diversification is generally characterised by a growing shift of surplus labour to arable farming and other petty activities that place a heavy pressure on the natural resource base of the pastoral system. The poor resort to cultivation mainly for survival. It is also tempting, at least in the short-run context, for wealthy households to commit their excess labour to dryland cultivation in pursuit of the traditional goal of livestock accumulation. With growing cereal supplements in the pastoralist diets, it apparently helps them to minimise livestock off-takes for cereal grain purchases. Given the prominence of household surplus labour shifts to crop cultivation, the current diversification behaviour displays a high covariate risk activity mix; thus, it may not be considered as being wholly driven by risk management motive (Little et al. 2001).

Ethiopia's recent policy statement on pastoral development emphasises transformation strategies that are fundamentally linked to non-pastoral options with a long-term goal of pastoralist sedentarisation (Ethiopia: MFA, 2002). In the Borana case, despite the apparent difficulties, pastoralism still remains the single most important source of surplus for welfare enhancing non-pastoral pursuits in the future. The livestock economy may still need to be a central focus for growth-oriented pastoral household resource commitment to non-pastoral activities. Growth-oriented non-pastoral activity participation is found to be significantly determined by household human capital acquisition. Past rangeland development projects, though their primary goal was livestock off-take, have failed to significantly achieve their commercialisation aims, principally because of the complete neglect of investment in human capital. From the empirical results, an effective integration of the pastoral 
economy into the broader exchange system is profoundly conditioned by the level of commitment to education and skill development in the area. The relatively skilled and literate younger Borana household heads, irrespective of location, display more diversified income portfolio preference than those with no literacy and exposure. In addition to its wider choice implications, human development investment will, therefore, substantially improve the pastoralist capacity to manage risk through welfare-enhancing diversified income portfolio adoption. Despite the apparent shortrun gains, a great deal of the current pastoralist diversification practice is otherwise largely inconsistent with the principle of livelihood sustainability in the Borana rangelands.

Another issue of practical policy concern is related to the received wisdom about pastoral households' non-pastoral labour supply. Traditionally, the Borana are cattle herders. The conventional belief about the pastoral mode of life is that the people have less taste for any occupation other than herding their cattle. However, the Borana are generally no longer reserved for non-pastoral jobs. A growing number of families are willing to earn non-pastoral income partly for investment on livestock. Properly planned labour-based development programmes may, therefore, significantly contribute to the growing cash needs of the poor and those with excess labour. Complementary investment on community level basic skills training programmes will have a substantial reward in this respect. The benefits of relatively costlier (possibly on per capita basis) investment efforts in pastoral areas, of course, should be evaluated in terms of avoiding the threats of long term humanitarian disasters. 


\section{TABLES}

Table 1: Summary of income shares by major sources and community wealth ranking categories

\begin{tabular}{|c|c|c|c|c|c|}
\hline \multirow[t]{3}{*}{ Income sources } & \multicolumn{5}{|c|}{$\begin{array}{c}\text { Income }^{\mathrm{a}} \text { per capita/month in Eth. Birr } \\
\text { (column percentages in parenthesis) } \\
\mathrm{N}=148\end{array}$} \\
\hline & \multicolumn{5}{|c|}{ Borana Community wealth ranking categories } \\
\hline & $\begin{array}{l}\text { Very } \\
\text { poor } \\
\text { (Qolle) }\end{array}$ & $\begin{array}{l}\text { Poor } \\
\text { (Deega) }\end{array}$ & $\begin{array}{c}\text { Middle } \\
\text { (Bultiqabesa) }\end{array}$ & $\begin{array}{l}\text { Rich } \\
\text { (Duresa) }\end{array}$ & $\begin{array}{l}\text { Total } \\
\text { share } \\
\text { (per } \\
\text { cent) }\end{array}$ \\
\hline Pastoralism & $9.0(\mathbf{2 5 . 6})$ & $30.4(62.4)$ & 48.0(74.7) & $121.3(\mathbf{7 9 . 3 )}$ & 72.0 \\
\hline Farming & $15.1(43.7)$ & $14.7(30.4)$ & $12.7(19.7)$ & $15.2(\mathbf{1 0 . 0})$ & 18.0 \\
\hline Non-farm non-pastoral & $11.0(30.7)$ & $3.5(7.2)$ & $3.6(5.6)$ & $16.3(\mathbf{1 0 . 7})$ & 10.0 \\
\hline Total & $35.0(\mathbf{1 0 0})$ & $48.6(100)$ & $64.3(100)$ & $155.0(\mathbf{1 0 0})$ & 100 \\
\hline
\end{tabular}

${ }^{a}$ It is for the survey period of nine months, which covers dry and wet seasons

Table 2: Distribution of non-pastoral income by source and wealth category $(\mathrm{N}=148)$

\begin{tabular}{|c|c|c|c|c|c|c|c|c|}
\hline \multirow[t]{2}{*}{$\begin{array}{c}\text { Income source (non- } \\
\text { pastoral) }\end{array}$} & \multicolumn{4}{|c|}{$\begin{array}{l}\text { Income shares by wealth ranks } \\
\text { (column percentages) }\end{array}$} & \multicolumn{4}{|c|}{ Percentage participating } \\
\hline & V.poor & Poor & Middle & Rich & V.poor & Poor & Middle & Rich \\
\hline Farming & 58.6 & 80.8 & 77.8 & 48.3 & 80.0 & 93.0 & 88.0 & 81.0 \\
\hline $\begin{array}{l}\text { NR resource-based } \\
\text { activities }^{\mathbf{a}}\end{array}$ & 8.4 & 2.8 & 11.1 & 0.0 & 48.0 & 19.0 & 23.0 & 0.0 \\
\hline $\begin{array}{l}\text { Livestock trade } \& \\
\text { small business }\end{array}$ & 0.0 & 0.0 & 4.7 & 41.3 & 0.0 & 0.0 & 2.0 & 27.0 \\
\hline Petty trade \& crafts ${ }^{\mathbf{b}}$ & 10.4 & 3.7 & 2.3 & 2.4 & 44.0 & 28.0 & 19.0 & 19.0 \\
\hline Wage work & 0.0 & 4.3 & 0.0 & 5.2 & 0.0 & 4.0 & 0.0 & 8.0 \\
\hline Casual labour & 11.1 & 3.1 & 0.0 & 0.0 & 48.0 & 19.0 & 0.0 & 0.0 \\
\hline Cash gifts \& transfers & 11.0 & 4.9 & 3.7 & 2.5 & 80.0 & 61.0 & 51.0 & 54.0 \\
\hline Poultry & 0.5 & 0.4 & 0.4 & 0.3 & 44.0 & 22.0 & 21.0 & 27.0 \\
\hline
\end{tabular}


Table 3: Definition and descriptive statistics of production function variables

\begin{tabular}{llcc}
\hline \multicolumn{1}{c}{ Variable } & \multicolumn{1}{c}{ Variable description } & Mean & SD \\
\hline $\mathbf{P}$ & Total value of pastoral production per household & 3478.0 & 6060.0 \\
\hline $\mathbf{L}$ & Total hours used in pastoral production activities & 2532.0 & 2120.0 \\
\hline $\mathbf{K}$ & $\begin{array}{l}\text { Total livestock units (TLU) representing livestock capital } \\
\text { inputs }\end{array}$ & 24.0 & 35.0 \\
\hline $\mathbf{C}$ & Total value of crops produced per household & 791.0 & 855.0 \\
\hline $\mathbf{F}$ & Labour hours used in crop production activities & 796.0 & 834.0 \\
\hline $\mathbf{N}$ & Cultivated land area in Sangas & 6.2 & 4.7 \\
\hline $\mathbf{O}$ & $\begin{array}{l}\text { Reported oxen use in crop production in average oxen } \\
\text { days }\end{array}$ & 9.5 & 6.1 \\
\hline $\mathbf{L}$ & Location dummy, 1 if Dhas; 0 otherwise & 0.21 & 0.41 \\
\hline $\mathbf{L}_{\mathbf{2}}$ & Location dummy, 1 if Dhoqolle; 0 otherwise & 0.28 & 0.45 \\
\hline $\mathbf{L}_{3}$ & Location dummy, 1 if Dubuluq; 0 otherwise & 0.21 & 0.41 \\
\hline${ }^{*}$ See text and endnote 6. & & \\
\hline
\end{tabular}

${ }^{*}$ See text and endnote 6 .

Table 4: The Cobb-Douglas and translog production function estimates for crop and livestock

\begin{tabular}{|c|c|c|c|c|}
\hline \multirow[t]{2}{*}{ Independent Variables } & \multicolumn{4}{|c|}{ Estimates $^{\mathrm{a}}$} \\
\hline & \multicolumn{2}{|c|}{ Pastoral Production } & \multicolumn{2}{|c|}{ Crop Production } \\
\hline & \multicolumn{2}{|c|}{ (Dependent variable: $\ln \mathrm{P}$ ) } & & \\
\hline & Coefficients & P-Values & & \\
\hline \multirow[t]{2}{*}{$\operatorname{lnL}$} & $0.1582^{* * *}$ & 0.009 & & \\
\hline & $(0.0596)$ & & & \\
\hline \multirow[t]{2}{*}{$\ln K$} & $0.8409^{* * * *}$ & 0.000 & & \\
\hline & $(0.0496)$ & & & \\
\hline \multirow[t]{2}{*}{ Constant } & $4.194^{* * * *}$ & 0.000 & & \\
\hline & $(0.3906)$ & & & \\
\hline $\mathrm{F}(2,142)$ & 283.7 & 0.000 & & \\
\hline $\mathrm{R}^{2}$ & 0.76 & & & \\
\hline $\mathrm{N}$ & 145 & & & \\
\hline \multirow[t]{2}{*}{$\ln F$} & & & $0.5787^{* * *}$ & 0.000 \\
\hline & & & $(0.1342)$ & \\
\hline \multirow[t]{2}{*}{$\ln \mathrm{N}$} & & & 0.0477 & 0.826 \\
\hline & & & $(0.2160)$ & \\
\hline \multirow[t]{2}{*}{$\ln \mathrm{O}$} & & & 0.1177 & 0.614 \\
\hline & & & $(0.2323)$ & \\
\hline \multirow[t]{2}{*}{$\mathrm{L}_{1}$} & & & $-0.6101^{* * * *}$ & 0.001 \\
\hline & & & $(0.1735)$ & \\
\hline \multirow[t]{2}{*}{$\mathrm{L}_{2}$} & & & 0.0169 & 0.931 \\
\hline & & & $(0.1936)$ & \\
\hline \multirow[t]{2}{*}{$\mathrm{L}_{3}$} & & & $-0.4909^{* *}$ & 0.032 \\
\hline & & & $(0.2252)$ & \\
\hline \multirow[t]{2}{*}{ Constant } & & & $2.522^{* * *}$ & 0.000 \\
\hline & & & $(0.6359)$ & \\
\hline $\mathrm{F}(6,101)$ & & & 24.7 & 0.000 \\
\hline $\mathrm{R}^{2}$ & & & 0.56 & \\
\hline $\mathrm{N}$ & & & 108 & \\
\hline
\end{tabular}


Table 5: Estimated return to labour from some selected activities in the Borana pastoral area (in Eth. Birr/hour)

\begin{tabular}{lccccc}
\hline & \multicolumn{5}{c}{ Activities and returns to labour per hour } \\
\cline { 2 - 6 } Type of return & Pastoralism & $\begin{array}{c}\text { Dryland } \\
\text { farming }\end{array}$ & $\begin{array}{c}\text { Natural- } \\
\text { Resource- } \\
\text { Based } \\
\text { activities }\end{array}$ & $\begin{array}{c}\text { Casual farm } \\
\text { work }\end{array}$ & $\begin{array}{c}\text { Unskilled } \\
\text { urban wage } \\
\text { rate }\end{array}$ \\
\hline Marginal returns & 0.18 & 0.35 & 0.54 & 0.56 & 0.88 \\
Average returns & 1.23 & 0.79 & 0.53 & - & - \\
\hline
\end{tabular}

${ }^{\mathrm{a}}$ It is for firewood collection and charcoal making

Table 6: The level of participation and non-pastoral income shares by category of activity portfolios

\begin{tabular}{|c|c|c|c|c|c|}
\hline \multirow{2}{*}{$\begin{array}{l}\text { Activity Portfolio } \\
\text { Categories }\end{array}$} & \multirow{2}{*}{$\begin{array}{c}\text { Per cent of } \\
\text { Households in } \\
\text { the Activity } \\
\text { Category }\end{array}$} & \multirow{2}{*}{$\begin{array}{c}\text { Per cent of } \\
\text { Female } \\
\text { Members in } \\
\text { NFNP } \\
\text { Categories }\end{array}$} & \multirow{2}{*}{$\begin{array}{c}\text { Average } \\
\text { Household } \\
\text { Income Per } \\
\text { Month (Birr) }\end{array}$} & \multicolumn{2}{|c|}{ Income Share (per cent) } \\
\hline & & & & $\begin{array}{l}\text { Non- } \\
\text { pastoral }\end{array}$ & $\begin{array}{c}\text { Non-farm } \\
\text { non-pastoral }\end{array}$ \\
\hline AP 1 & 7.4 & 42.1 & 2298 & 36 & 22 \\
\hline AP 2 & 25 & 51.1 & 279 & 49 & 18 \\
\hline AP 3 & 12.9 & 76.7 & 240 & 69 & 33 \\
\hline AP 4 & 45.2 & NA & 460 & 47 & $2.4^{*}$ \\
\hline AP 5 & 9.5 & NA & 481 & $3^{*}$ & $3 *$ \\
\hline
\end{tabular}

Table 7: Multinomial logit estimates of the determinants of pastoral household activity choices

\begin{tabular}{|c|c|c|c|c|}
\hline \multirow[b]{3}{*}{$\begin{array}{l}\text { Explanatory } \\
\text { Variables }\end{array}$} & \multicolumn{4}{|c|}{ Category of Activity Portfolios } \\
\hline & AP 1 vs AP4 & AP 2 vs AP4 & AP 3 vs AP4 & AP 5 vs AP4 \\
\hline & Coefficients & Coefficients & Coefficients & Coefficients \\
\hline \multirow[t]{2}{*}{ AGE } & $-0.134^{* * *}$ & -0.009 & 0.001 & $0.041^{*}$ \\
\hline & $(0.0528)$ & $(0.0149)$ & $(0.0249)$ & $(0.0245)$ \\
\hline \multirow[t]{2}{*}{ FEMHEAD } & $-32.03^{* * *}$ & $1.53^{* *}$ & $1.92^{* *}$ & 0.552 \\
\hline & $(1.203)$ & $(0.7281)$ & $(0.9038)$ & $(0.9335)$ \\
\hline \multirow[t]{2}{*}{ HHSIZE } & $0.305^{*}$ & $0.208^{*}$ & $0.346^{* *}$ & -0.171 \\
\hline & $(0.1679)$ & $(0.1197)$ & $(0.1728)$ & $(.1697)$ \\
\hline \multirow[t]{2}{*}{ MALE15-64 } & -0.033 & 0.420 & 0.576 & $-1.52^{*}$ \\
\hline & $(0.5678)$ & $(0.2762)$ & $(0.3940)$ & $(0.9471)$ \\
\hline \multirow[t]{2}{*}{ STOCKSIZE } & $0.028^{*}$ & $-0.116^{* * *}$ & $-0.200^{* * *}$ & 0.014 \\
\hline & $(0.0142)$ & $(0.0413)$ & $(0.0527)$ & $(0.0135)$ \\
\hline \multirow[t]{2}{*}{ EDUCATION } & $1.63^{* * *}$ & 0.587 & $-32.13^{* * *}$ & $-33.25^{* * *}$ \\
\hline & $(0.5360)$ & $(0.6686)$ & $(1.145)$ & $(1.333)$ \\
\hline \multirow[t]{2}{*}{ DCENTRE } & -0.019 & 0.0001 & $-0.045^{* *}$ & -0.007 \\
\hline & $(0.0145)$ & $(0.0098)$ & $(0.0194)$ & $(0.0160)$ \\
\hline CONSTANT & 0.595 & -0.767 & -1.43 & -2.26 \\
\hline Log likelihood & -131.5213 & & & \\
\hline $\operatorname{LR} \chi^{2}(28)$ & 136.74 & & & \\
\hline P-value & 0.000 & & & \\
\hline $\mathrm{N}$ & 148 & & & \\
\hline
\end{tabular}




\section{NOTES}

1. Camels and goats have gained economic significance only after time, particularly in response to recurrent droughts. They have no cultural significance and especially camel was formally allowed only after the Abaya Haro period (1561-1569) (interview with Borbor Bule).

2. The figure for the highest quartile may be an underestimate due to the well-known difficulty of complete enumeration of the wealth of the rich.

3. Livestock traders are all men, but rich traders often own shops and related small business activities that are run by female household members. In some cases, female members of wealthy households are found to participate in petty trading activities for extra income earnings.

4. The Cobb-Douglas model is a widely used functional form due to its relative simplicity in estimation and interpretation. It, however, restrictively implies unitary elasticity of substitution (Griffiths et al. 1993). The translog model is often specified as an alternative flexible functional form though still with various complications of its own (Greene 1980, Jacoby 1993, Abdulai and Regmi 2000). A joint test of significance of the relevant parameters in our initially specified translog crop production function rejected the appropriateness of the model. For pastoral production, the computed return estimates based on the translog model are found to be nearly identical with the results reported here using the C-D technology.

5. This is expressed in livestock units based on conversion factors: cows (1), heifers (0.75), calves (0.34), young male (0.54), bull/steer (1), small stock (0.13), camel (1.25), horse and mule (1), donkey (0.74).

6. The district Department of Agriculture considers six Sangas as being equal to one hectare though our interview with their experts gains no evidence whether this is based on systematic field measurement. Our actual field measurement, though limited to a few plots in Romiso village, shows that four Sangas $=$ one hectare.

7. Livestock are mobile and the inclusion of village effects in the pastoral production function is of less technical appeal.

8. A model of the form $\mathrm{Y}=\mathrm{a} \mathrm{X}^{\mathrm{b}}$ is estimated based on 14 observations of charcoal makers and fuel wood collectors; here $\mathrm{Y}$ is the total value, and $\mathrm{X}$ stands for labour hours. The estimated elasticity coefficient is 1.0 and statistically significant at 1 per cent level. The estimated marginal and average productivities are almost equal due to the absence of any significant input contribution other than labour.

9. The casual farm work average earning and unskilled urban wage rates are recorded here in the marginal returns line, with the consideration that these rates signal alternative income opportunities to the pastoralist. We are grateful to one of the anonymous referees for the suggestion.

10. See (Cook 1996) for similar interpretations in other contexts.

11. The education variable is found to be statistically insignificant in two recent highland Ethiopia studies (Block and Webb 2001, Woldenhanna and Oskam 2001). The Tigrary region result by Woldenhanna and Oskam might partly reflect the induced income diversification financed by the massive government and NGO supported unskilled off-farm employment schemes in the area. 


\section{REFERENCES}

Abdulai, A. and Regmi P.P. (2000) Estimating labour supply of farm households under nonseparability: empirical evidence from Nepal. Agricultural Economics, 22, pp. 309-320.

Barrett, C., Reardon T. and Webb P. (2001a) Non-farm income diversification and household livelihood strategies in rural Africa: concepts, dynamics, and policy implications. Food Policy, 26, pp. 315-331.

Barrett, C., Bezuneh, M. and Aboud A. (2001b), Income diversification, poverty traps and policy shocks in Côte d'Ivoire and Kenya. Food Policy, 26, pp. 367384.

Ben-Akiva M. and Lerman S. (1985) Discrete Choice Analysis: Theory and Application to Travel Demand (Massachusetts: The MIT press).

Block, S. and Webb P. (2001) The dynamics of livelihood diversification in postfamine Ethiopia. Food Policy, 26, pp. 333-350.

Campbell, D.J. (1999) Response to drought among farmers and herders in southern Kajiaro district, Kenya: a comparison of 1972-1976 and 1994-1995. Human Ecology, 27, pp. 377-417.

Casley, D.J. and Lury D. A. (1987), Data Collection in Developing Countries (Oxford: Oxford University Press).

Coast, E. (2002) Maasai socioeconomic conditions: a cross-border comparison. Human Ecology, 30, 2002.

Cook, S. (1996) Surplus labour and productivity in Chinese agriculture: evidence from household survey data. IDS working paper No. 43, Institute of Development Studies, University of Sussex.

Coppock, D.L. (1994) The Borana Plateau of Southern Ethiopia: Synthesis of Pastoral Research, Development and Change. (ILCA: Addis Ababa Ethiopia).

Dahl, G. (1979) Suffering Grass: Subsistence and Society in Waso Borana (Stockholm Studies in Social Anthropology: Stockholm).

Dahl, G. and. Hjort, A. (1976) Having Herds: Pastoral Herd Growth and Household Economy (Stockholm Studies in Social Anthropology 2: Stockholm).

Dercon, S. and Krishnan, P. (1996) Income portfolios in rural Ethiopia and Tanzania: choices and constraints. The Journal of Development Studies, 32, pp. 850-875.

Desta, S. and Coppock, D.L. (2004) Pastoralism under pressure: tracking system change in southern Ethiopia. Human Ecology, 32, pp. 465-486.

Ellis, F. (1998) Household strategies and rural livelihood diversification, The Journal of Development Studies, 35, pp. 1-38.

Ellis, F. (2000) Rural Livelihoods and Diversity in Developing Countries (New York: Oxford University Press).

Ethiopia, MFA (2002) Statement on Pastoral Development Policy, Addis Ababa.

Fratkin, E. (1998) Ariaal Pastoralists of Kenya: Surviving Drought and Development in African Arid Lands (Boston: Allyn and Bacon).

Fratkin, E. and Mearns, R. (2003) Sustainability and pastoral livelihoods: lessons from East African Maasai and Mongolia. Human Organization, 62, pp. 112112.

Greene, W. (1980) On the estimation of a flexible frontier production model. Journal of Econometrics, 13, pp. 101-115. 
Griffiths, W.E., Hill, R.C., and Judge, G.G. (1993) Learning and Practicing Econometrics (New York: John Wiley \& Sons, Inc.).

Horowitz, M.M and Little, P.D. (1987) African pastoralism and poverty: some implications for drought and famine, in: Glantz (ed.) Drought and Hunger in Africa (Cambridge: Cambridge University Press).

Huqqaa, G. (n.d.), The $37^{\text {th }}$ Gumii Gaayo assembly. Norwegian church aid: Addis Ababa, Ethiopia.

Jacoby, H. (1992) Productivity of men and women and the sexual division of labour in peasant agriculture of the Peruvian Sierra. Journal of Development Economics, 37, pp. 265-287.

Jacoby, H. (1993) Shadow wages and peasant family labour supply: an econometric application to the Peruvian Sierra. Review of Economic Studies, 60, pp. 903921.

Judge, G., Griffiths, W., Hill, C., Lütkepohl, H. and Lee, T. (1985) The Theory and Practice of Econometrics, New York: John Wiley and Sons.

Legesse, A. (2000) Oromo Democracy : An Indigenous African Political System (Lawrenceville, NJ: Red Sea Press).

Legesse, A. (1973) Gada: Three Approaches to the Study of African Society (New York: Praeger Publishers).

Little, D.P., Smith, K., Cellarius, B., Coppock, D.L. and Barrett, B.C. (2001) Avoiding disaster: diversification and risk aversion among East African herders. Development and Change, 32, pp. 401-433.

McCabe, T. (2003) Sustainability and livelihood diversification among the Maasai of northern Tanzania. Human Organization, 62, pp. 100-111.

Niehof, A. (2004) The significance of diversification for rural livelihood systems. Food Policy. 29, pp. 321-338.

Oba, G. (1998) Assessment of indigenous range management knowledge of the Booran pastoralists of southern Ethiopia, unpublished report.

Polzin, P. and MacDonald, P. Off-farm work: a marginal analysis. The Quarterly Journal of Economics, 85, pp. 540-545.

Pratt, D., Gall, F. and Cornelis de Haan (1997) Investing in Pastoralism: Sustainable Natural Resource Use in Arid Africa and Middle East, World Bank Technical Working Paper No. 365, Washington, DC World Bank.

Reardon, T. (1997) Using evidence of household income diversification to inform study of the rural nonfarm labour market in Africa. World Development, 25, pp. 735-747.

Reardon, T., Berdegué, J. and Escobar, G. (2001) Rural nonfarm employment and incomes in Latin America: overview and policy implications. World Development, 29, pp. 395-409.

Rutten, M.M. (1992) Selling Wealth to Buy Poverty: The Process of Individualization of Landownership Among the Maasai Pastoralists of Kajiado District, Kenya, 1890-1900, Nijmegen studies in development and cultural change, Vol. 10, Verlag breitenbach Publishers, Saarbrucken, Germany.

Sandford, S. (1983) Management of Pastoral Development in Third World, London: Wiley, Chichester and Overseas Development Institute.

Singh, I., Squire, L. and Strauss, J. (eds) (1986) Agricultural Household Models (Baltimore: Johns Hopkins). 
Skoufias, E. (1994) Using shadow wages to estimate labour supply of agricultural households. American Journal of Agricultural Economics, 76, pp. 215-227.

Sperling, L. and Galaty, J.G. (1990) Cattle, culture, and economy: dynamics in East African pastoralism, in: J.G. Galaty and D.L. Johnson (eds) The World of Pastoralism: Herding Systems in Comparative Perspective (London: Guilford Press).

Spencer, P. (1997) The Pastoral Continuum: The Marginalization of Transition in East Africa (Oxford: Oxford University Press).

Swift, J. (1986) The economics of production and exchange in West African pastoral societies, in: M. Adamu and A.H.M. Hirk-Greene (eds), Pastoralists of the West African Savanna, (Manchester: Manchester University Press), pp.175190.

Swift, J. and Hamilton, K. (2001) Household food and livelihood security, in: S. Devereux and S. Maxwell (eds), Food Security in Sub-Saharan Africa (London: ITDG Publishing) pp. 67-92.

Webb, P. and Coppock, D.L. (1997) Prospects for pastoralism in Semi-Arid Africa, in: S. Vosti and Thomas Reardon (eds), Sustainability, Growth and Poverty Alleviation (Baltimore: Johns Hopkins University Press), pp.246-260.

Woldenhanna, T. and Oskam A. (2001) Income diversification and entry barriers: evidence from Tigray region of northern Ethiopia. Food Policy, 26, pp. 351365. 